\title{
Mid Cenozoic freshwater wetlands of the Sunda region
}

\author{
Robert J. MORLEY, ${ }^{1,2,3,{ }^{*}}$ Harsanti P. MORLEY ${ }^{2}$ \\ ${ }^{1}$ Department of Earth Sciences, Royal Holloway University of London, TW20 0EX Egham; ${ }^{2}$ Palynova Ltd., 1 Mow Fen Road, CB6 \\ 1 PY Littleport, United Kingdom; ${ }^{3}$ NIKO Asia Ltd., Plaza City View, J1 Kemang Timur 22, 12510 Jakarta, Indonesia
}

*Corresponding author: pollenpower@palynova.com

\begin{abstract}
Sunda region was the scene of widespread rifting during the mid-Cenozoic, resulting in the development of numerous large lakefilled rifts, analogous in scale to the rift valley system of East Africa. The Tonle Sap in Cambodia forms the closest modern analogue for these lakes in the Southeast Asian region. Many of the palaeolakes were long lived, continuing uninterrupted as open lakes for several millions of years during the Oligocene. Smaller rift systems infilled with fluvial sediments, but the majority remained as lakes, and with Late Oligocene subsidence, were transformed by brackish, and in the earliest Miocene, by marine incursion, into large inland seas. These seas reached their greatest extent at the time of the mid Miocene thermal maximum. This paper describes the development and eventual demise of these lakes following marine transgression, and, based on their rich content of pollen and spores, illustrates the variety of fresh and brackish water swamp communities which developed around their margins. The marginal swamps can be divided into: i) seasonally inundated swamps, mainly during the Oligocene, characterised by Barringtonia, Lagerstroemia and grasses/sedges; ii) fern swamps from the Late Oligocene onward; iii) alluvial swamps, often characterised by Pandanus; and iv) peat swamps. The latter can be differentiated into kerapah peat swamps, first occurring during the Oligocene, and basinal peat swamps, becoming widespread from the Early Miocene onward.
\end{abstract}

Key words: Sundaland, Cenozoic, palaeolakes, wetland vegetation, succession.

Received: February 2013. Accepted: June 2013.

\section{INTRODUCTION}

This paper describes the nektonic and freshwater swamp plant communities which developed within and around the extensive palaeolakes and inland seas present across the majority of Sunda shelf during the mid Cenozoic (Fig. 1). The Cenozoic development of evergreen and seasonal forests (Morley, 2000, 2006, 2012) and mangroves (Morley, 2000) for this region has been previously assessed, but the former distribution of freshwater wetlands has been given just scant attention, despite the fact that their presence as a major pollen source in Cenozoic marine deposits has been known for many years (Muller, 1972). This paper attempts to remedy that, and, together with a sister paper on peat swamps (Morley, 2013), to outline the Cenozoic history of the majority of wetland vegetation types for the region now in place. For the northern Sunda shelf, this is possible following the recent publication of the distribution of palaeolakes and inland seas for different time slices of the Cenozoic by Shoup et al. (2013).

The Sundaland palaeolakes are supposed to have been extremely large, and from the Southeast Asian region, only Tonle Sap in Cambodia can be visualised in any way as a small present day analogue. The big rift lakes of East Africa are much more comparable in size and depth, and the similarities with the lakes of East Africa will be discussed further below. The lakes occurred across a wide range of latitudes, and hence climates, from the equatorial zone, typically with everwet climates, to 15 degree north at which latitude climates were invariably distinctly seasonal and warm temperate (Songtham et al., 2003). The lakes harboured rich algal communities (Cole, 1992), and fish (Sanders, 1934). In addition to algal communities occurring in the freshwater lakes, and the occurrence of foraminifera when salinities became brackish, the lacustrine sediments contain rich pollen and spore records which indicate that lake margin marshes and swamps were of great variety, and included seasonally flooded, tree-dominated freshwater swamps and herbaceous marshes, fern swamps, ombrotrophic and topotrophic, tree-dominated peat, Pandanus swamps and, with the onset of brackish and marine conditions during the Early Miocene, and mangrove swamps occurring in areas with tidal and brackish influence.

This paper attempts to illustrate the variety of freshwater marsh and swamp plant communities which would have bordered these lakes and inland seas from the Late Eocene, when many of the lakes first formed, until the Middle Miocene, by which time virtually all the lakes had been drowned by marine transgression. 


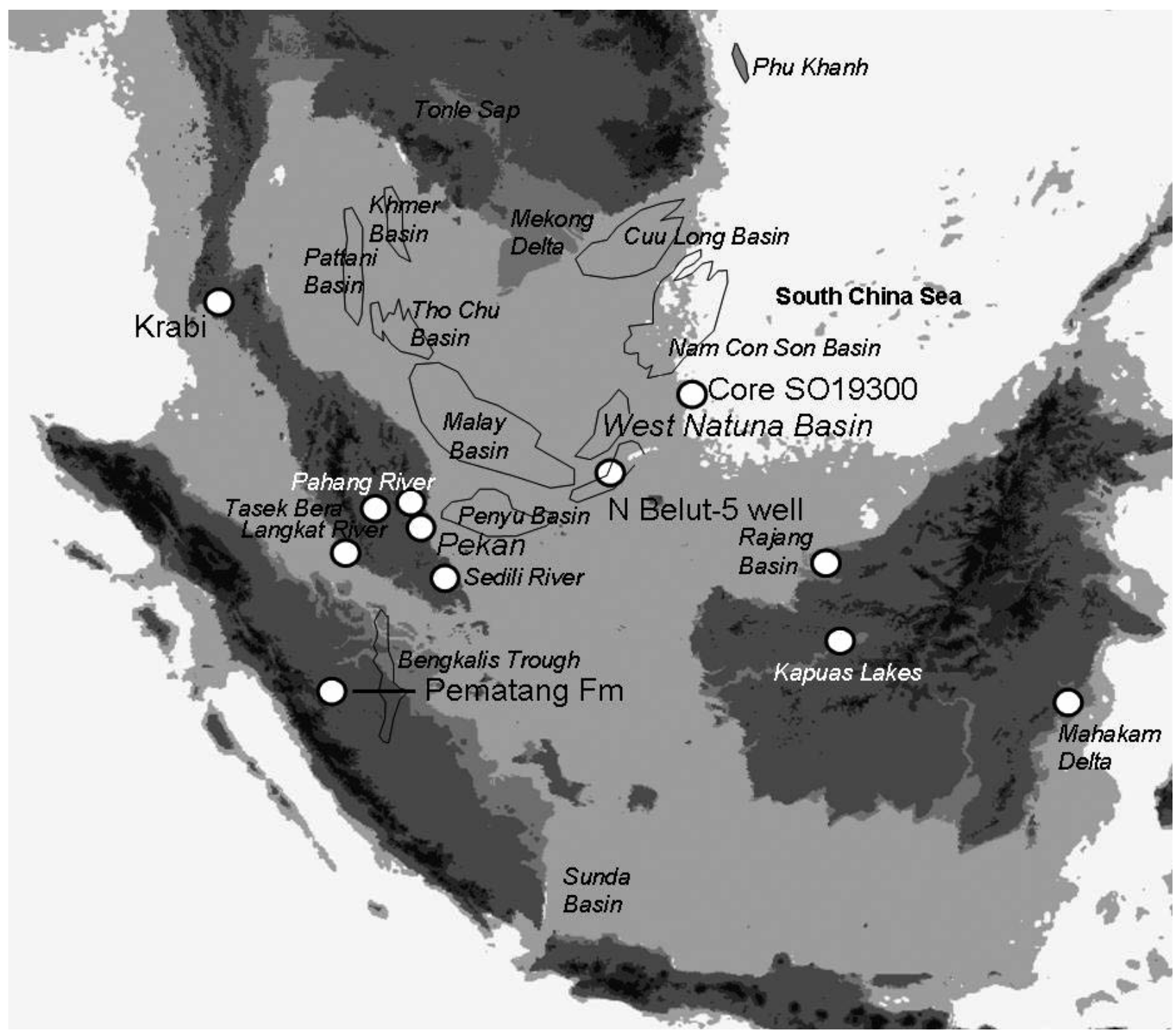

Fig. 1. Sunda shelf comprising the locations under study. Map modified from Sathiamurthy and Voris (2006).

\section{GEOLOGICAL SETTING OF MID CENOZOIC PALAEOLAKES}

The Sunda shelf is characterised by the widespread occurrence of lacustrine sediments, which accumulated in freshwater and brackish lakes during the mid-Cenozoic (Katz and Kelly, 1987; Cole and Crittenden, 1997). Lacustrine facies extend from West Java and Sumatra, through the Malay basin offshore West Malaysia, West Natuna in Indonesia, the gulf of Thailand, and East to the Nam Con Son and Coo Long basins offshore South Vietnam. It is these lacustrine sediments which have sourced a major part of the hydrocarbons reservoired across South East Asia (Robinson, 1987).
The tectonic development of the basins in which these lakes occurred remains poorly understood, despite extensive geological studies across the area (White and Wing, 1978; Ginger et al., 1993; Hall and Morley, 2004). This may be because individual basins have often been examined in isolation, often depositional systems have been appraised independently either side of national boundaries (Leong, 1999). Also, because the basins were mostly freshwater, at least during their initial stage of development, they lack marine fossils, and few attempts have been made to correlate or compare the lacustrine successions between different geographical areas using palynology.

One of the reasons for the poor dating is that palynology, utilising age restricted pollen and spores alone - 
which include virtually the only age-restricted microfossils in these successions - provides a basic stratigraphic resolution which is too broad (Germeraad et al., 1968; Morley, 1977, 1991) to make useful regional comparisons. However, if palynological data is generated and examined from a sequence biostratigraphic perspective (Morley, 1996, 2000; Morley et al., 2011), taking into account patterns of climate change and the effect of sea and lake level change on vegetation during successive cycles of base level change, a degree of stratigraphic precision can be reached which equals or exceeds that coming from planktonic microfossils (Morley et al., 2011). The sequence biostratigraphic units which can be interpreted using this approach can be consistently correlated with basins from the gulf of Thailand to the Nam Con Son basin to the south of the Mekong delta in Vietnam, and across all main political boundaries (Morley et al., 2011). The resulting chronostratigraphic control has recently permitted the palaeogeography of these depositional systems to be compared across the region for the first time (Shoup et al., 2013). Ages applied throughout follow the current International Commission for Stratigraphy scheme.

Furthermore, the northern Sunda shelf basins, from the distal Nam Con Son basin, adjacent to the South China sea, through West Natuna and the Malay basins to the proximal Thai basins, are interlinked, and the succession of events seen in any one basin typically has features in common with more distal basins. The best chronostratigraphic control is thus in the easternmost Nam Con Son basin, which has the greatest marine influence and most complete record of marine index fossils. Sediments are therefore best dated in Nam Con Son, then age equivalent packages in more proximal basins dated through correlation using the sequence biostratigraphic approach. However, in many ways it is the most distal Nam Con Son basin which has proved most difficult to understand (Morley et al., 2011), due to its more complex tectonics (Swiecicki and Maynard, 2009) and this has impacted the understanding of more proximal basins.

Most studies infer that the northern Sunda shelf basins consist of a succession of half grabens, which are often filled with organic-rich lacustrine facies. Taking palaeogeography and palynological evidence into account, this model seems simplistic and needs substantial modification. Firstly, many of the rifts are filled with thick, uninterrupted lacustrine deposits, sometimes with turbidites, suggesting permanent and long lived-lakes, with continuous lacustrine deposition over millions of years, suggestive of deep rifts. Secondly, the common occurrence of pollen of montane conifers in the lacustrine sediments, such as Abies, Picea and Tsuga (Pinaceae), together with regular pollen of Alnus (Betulaceae), and sometimes the conifers Cedrus and Keeteleeria (Muller 1966, 1972; Morley, 1998), suggests the presence of extensive uplands adjacent to the lakes, with greater altitudinal extremes than would be the case with a simple basin and range
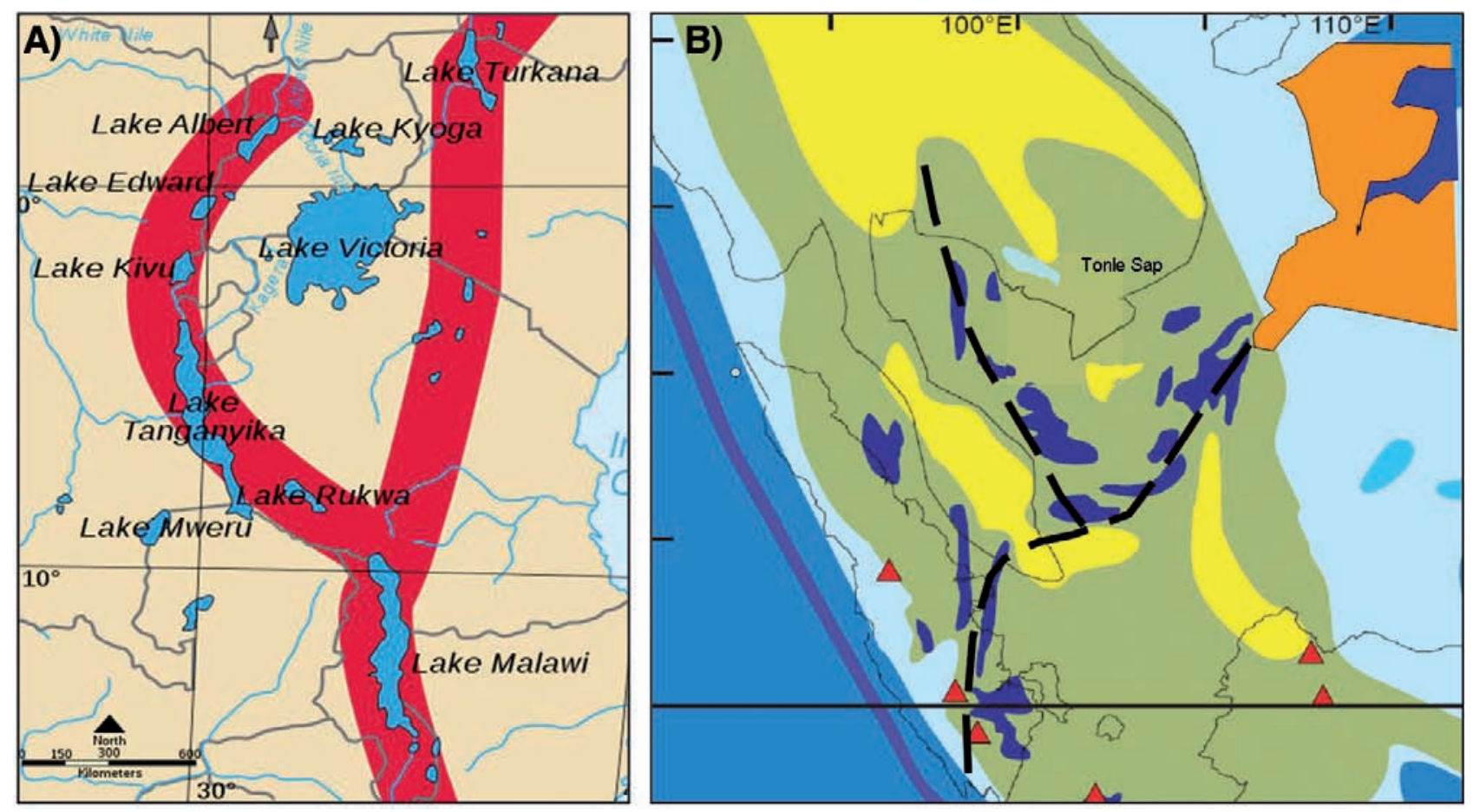

Fig. 2. Comparison of Early Oligocene Sunda and East African rifts at the same scale. For sources of Sunda palaeogeography see Fig. 4. 
model, and in line with a setting more comparable to a major rift system. The montane conifers present suggest an upland setting with significant areas at altitudes of at least $1500 \mathrm{~m}$ asl as the taxa listed above do not occur anywhere in the region below $1500 \mathrm{~m}$ altitude, some are restricted to higher altitudes (Ohsawa, 1990, 1992; Morley, 2000) (Figs. 2 and 3). Also, due to the principle of phylogenetic niche conservatism (Wien and Graham, 2005), it is unlikely that their ecological requirements in the past were significantly different from today's. The combined algal and gymnosperm palynological record therefore suggests substantial altitudinal relief from rift valley floor to mountain top.

\section{COMPARISON WITH EAST AFRICA}

Comparison of the distribution and size of palaeolakes across Sunda and also through Sumatra/Java suggests many similarities in scale and distribution to the rift valley lakes of East Africa (Figs. 2 and 3). The East African rift system (Baker and Wohlenberg, 1971) is an active continental rift zone that extends from lake Turkana in Ethiopia to lake Malawi in the South, covering a distance of over $2500 \mathrm{~km}$. For much of its length, it divides into western and eastern arms. The western arm is more seismically active and characterised by major graben formation with deep sediment-filled lakes such as lakes Tanganyika, Kivu and Albert, whereas the eastern rift is more volcanically active with fewer lakes, but includes lakes Turkana and Natron (Saemundsson, 2010). The East African rift system is thought to have developed in the mid Cenozoic following upwarping relating to the development of a mantle plume (Baker and Wohlenberg, 1972). The main phase of rifting and lake infill was from the Late Miocene 8 million years (Ma) onward (lake Albert, Tanganyika) with lake Melawi from $6 \mathrm{Ma}$ and Edward from $4 \mathrm{Ma}$. Despite different times of initiation, some lakes show similar stratigraphic successions, especially lakes Melawi and Tanganyika (McGregor, 2012).

It is suggested here that the Sunda and Sumatran grabens form a failed rift system analogous in extent to the present day rift system of East Africa, with a triple junction in the vicinity of Penyu basin. There are close similarities in terms of size, lake distribution, basin infill and the duration of lacustrine sedimentation (see below), but differences in terms of extent of volcanic activity. It has previously been suggested by Ngah et al. (1996) that the Malay, Penyu and West Natuna basins developed as rift arms of a triple junction above a continental crustal dome over a mantle plume. There is little physical evidence or doming, which could be hinted at, for instance from radial outwards flow of rivers, or excessive erosion at the dome centre. More likely, the rift system relates to the formation of a depression centred on the triple junction relating to extension, rather than to a crustal high.

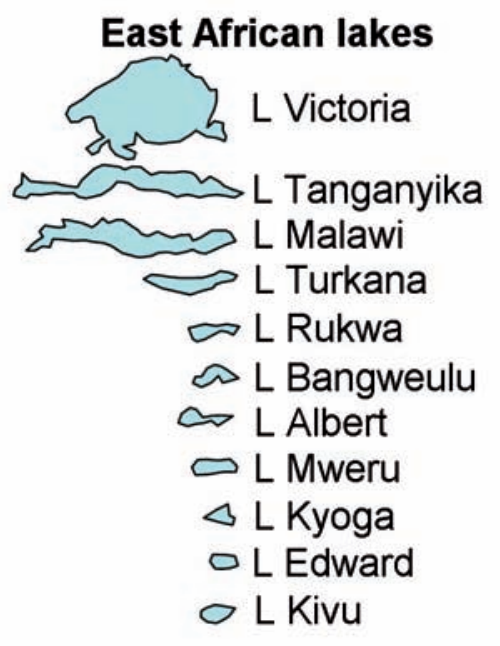

Sunda Oligocene lakes

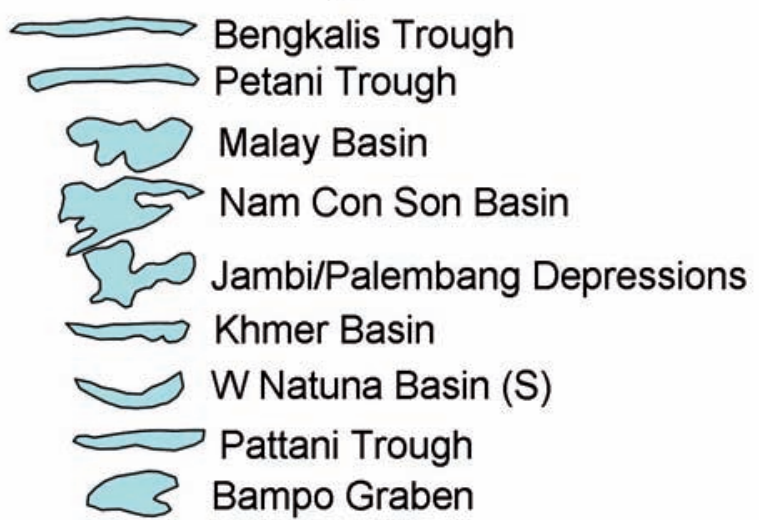

Penyu Basin

$\checkmark$ Tra Trang Basin

Coo Long

$\approx$ N Malay Basin

W Natuna Basin $(\mathrm{N})$

$\triangle$ Ombilin Basin

Fig. 3. Comparison of synrift basin sizes in East Africa and Sunda. 


\section{RELATIONSHIP WITH THE SOUTH CHINA SEA SPREADING CENTRE}

The northern Sunda shelf rift system also forms a mid Cenozoic extension of the seafloor spreading system of the South China sea described by Briais et al. (1993), and current dating shows a very close relationship with the development of this system in terms of timing (Fig. 4A). Rifting is thought to have begun in the Late Eocene (Ginger et al., 1993; Morley et al., 2011), and probably occurred at the same time as rift initiation in the South China sea, with the synrift phase (the period of active faulting when sedimentation was confined to the rift) coinciding with the initial stage of rifting from the Late Eocene until about $31 \mathrm{Ma}$, in the mid Oligocene. This timing would be consistent with the presence of Late Eocene mammalian faunas in synrift deposits at Krabi in southern Thailand (Ducrocq et al., 1998; Chaimanee et al., 1997), suggesting that the initiation of rifting was more or less consistent across Sunda. After $31 \mathrm{Ma}$, rifting ceased in the Sunda shelf basins, but seafloor extension began in the region of the South China sea. Following the cessation of rifting on the Sunda shelf and the failing of the Penyu triple junction, the area went into a phase of thermal sag (the area subsides after it cools following the cessation of rifting), which continued throughout the time of seafloor spreading of the South China sea until about $15 \mathrm{Ma}$, after which time spreading apparently ceased and West Natuna and southern Malay basins underwent a phase of compression and inversion, resulting in the formation of a widespread

A)

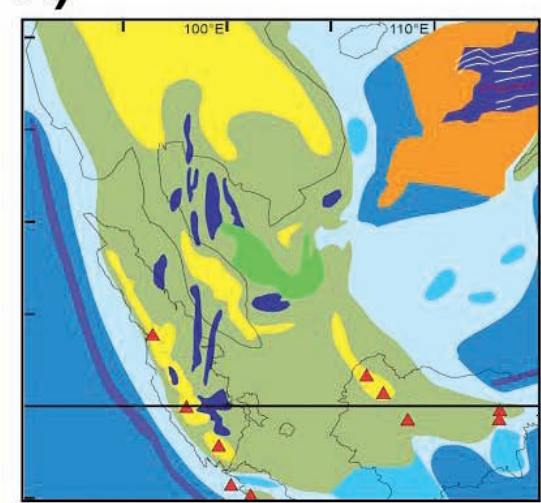

$24 \mathrm{Ma}$

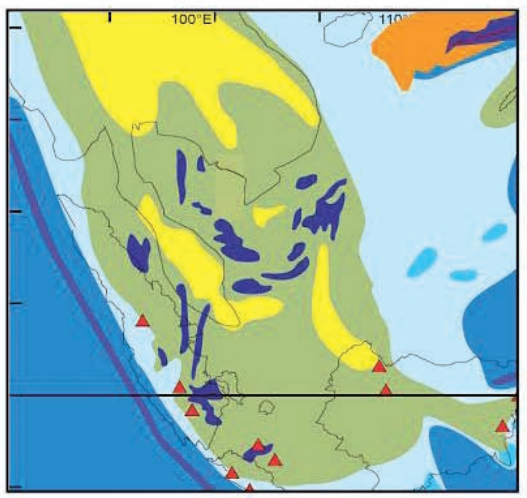

$30 \mathrm{Ma}$

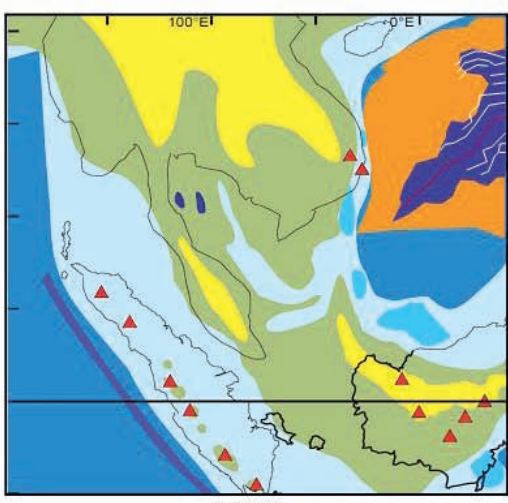

$16 \mathrm{Ma}$

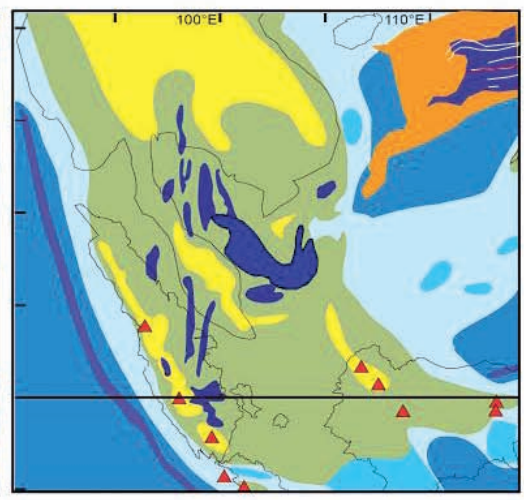

$27 \mathrm{Ma}$

\section{B)}

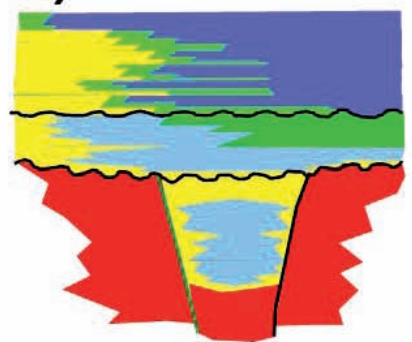

$16 \mathrm{Ma}$

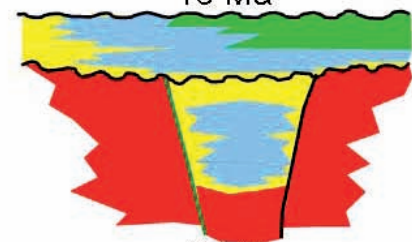

$24 \mathrm{Ma}$

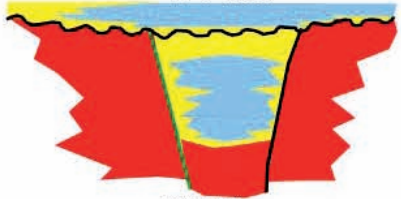

$27 \mathrm{Ma}$

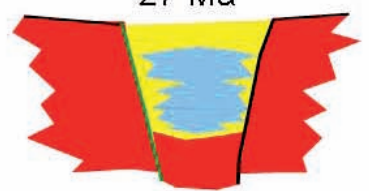

$30 \mathrm{Ma}$

Fig. 4. A) Palaeogeographic maps for $24 \mathrm{Ma}$ (Late Oligocene sag phase with brackish water lakes), $16 \mathrm{Ma}$ (inland seas developed across Sunda shelf, with widespread marine transgression across Sumatra and Java during Middle Miocene sag phase), 30 Ma (Early Oligocene synrift phase with freshwater lake-filled rifts at $30 \mathrm{Ma}$ ), and $27 \mathrm{Ma}$ (freshwater lakes expanding during Late Oligocene sag phase following cessation of rifting at $27 \mathrm{Ma}$ ). Palaeocoastlines and marine palaeogeography are modified from Hall (2012), South China sea spreading from Briais (1993) as presented in Hall (2002), Sunda shelf lakes and inland seas from Shoup et al. (2012), Sumatran and Java sea lakes mainly from Moulds (1989), palaeoaltitudes from Hall (2012) for Borneo, Sumatra and Indochina, and Shoup et al. (2012) for Sunda shelf. B) Development of lacustrine systems, with lake-filled grabens, for the same time periods. Red=basement; yellow=fluvial; light blue=freshwater lacustrine; dark green=brackish lake; dark blue=normal marine; light green=mangrove swamps. 
period of non-deposition across much of the area during the mid Miocene (Fig. 4B).

\section{REGIONAL SIMILARITIES AND DIFFERENCES IN RIFT INFILL}

All of the rift systems, from the Java sea, through Sumatra, the Malay and Thai basins, West Natuna and Nam Con Son show some general similarities in succession, typically presenting an initial phase of coarse grained fluvial deposits followed by lacustrine sedimentation and then by further fluvial deposition at the end of the synrift succession. At the beginning of the regional sag phase there was often a resumption of lacustrine deposition. On the Sunda shelf, Late Oligocene brackish and Early Miocene marine transgressions eventually resulted in the transformation of many of the basins into extensive inland seas, whereas across Sumatra and Java, post-Oligocene subsidence was greater and all the rifts in those areas were submerged by marine transgression from the basal Early Miocene (Fig. 4A).

However, different rift basins showed slightly different patterns of development, depending on factors such as the size and depth of depressions, and also latitudinal position, with rifts in equatorial localities such as the Sunda basin filling with coal-forming peats from the time of the Late Oligocene thermal maximum (represented by the coaly Talang Akar Formation). The Ombilin basin in Central Sumatra shows a similar pattern but different timing of peat formation, and shallow rift systems, such as some of the gulf of Thailand troughs, filled with mainly fluvial sediments without extensive lake development. However, the big rift systems of West Natuna, the Malay basin, Nam Con Son and Pattani developed thick successions of lacustrine sediments, in which thick shale successions rich in algal palynomorphs accumulated seemingly without interruption over several million years.

\section{METHODS}

This review takes into account published data on lacustrine depositional systems, including Cole (1992), Cole and Crittenden (1997) Morley et al. (2003) and Morley (2012), but mainly relies extensively on unpublished palynological studies undertaken from across the region during the course of various petroleum exploration programmes over the past 30 years and involving thousands of samples. These analyses were invariably obtained from rock chippings (cuttings) derived from petroleum exploration wells rather than conventional cores, and hence give a generalised indication of assemblages rather than the precise assemblages which would be obtained from the analysis of conventional core or outcrop samples (each sample consists of homogenised rock chippings from up to $10 \mathrm{~m}$ of stratigraphic section). Samples were typically analysed at 10, 20 or $30 \mathrm{~m}$ intervals over sections of in- terest. Samples were processed by removing carbonates and silicates by digestion in hydrochloric and hydrofluoric acids, followed by removal of other inorganics by flotation in a heavy liquid. Palynomorphs were then concentrated and cleared by oxidation in nitric acid. Analysis mostly involved systematic logging until a minimum of 100 terrestrially-derived palynomorphs were logged. In illustrating ecological successions, only a few pollen and algal palynomorph distributions are shown from characteristic facies from different basins. Typically, datasets yield 150-200 palynomorph types and are complex. Diagrams were initially created using the program Stratabugs and are presented showing the taxa discussed together with summaries mostly showing i) mangrove, ii) nonmangrove pollen, iii) spores and iv) algal palynomorphs. Diagrams are displayed using total non-mangrove pollen as the pollen sum with spectra for mangroves, spores and algae calculated outside the sum. Pollen and spores are placed into ecological groups based on parent plant ecology in the Malay peninsula. However, the taxa need not be entirely confined to those groups, especially in locations distant from the Malay peninsula.

\section{THE PALAEOLAKES}

The Sunda palaeolakes can be divided into four phases of development (Fig. 4). The first phase was during the Late Eocene to Early Oligocene, during the synrift phase, when many lakes were probably deep (sufficient to permit development of turbidites), and enclosed within the rifts, hence of limited lateral extent. Many lakes became filled with fluvial deposits toward the end of the synrift phase. This phase led to the accumulation of the Tien Cau formation in the Nam Con Son basin; the Lama, Benua and Belut formations in West Natuna; probably the undrilled seismic groups N, O and P in Malay basin; the Pematang formation of Sumatra; and the Banuwati formation of the Sunda basin. The second phase was during the postrift sag period, during earlier Late Oligocene, when widespread lakes developed especially in the Malay and West Natuna basins. This led to the accumulation of the Fluvial Cau formation in Nam Con Son; the Gabus formation in West Natuna; seismic group M and possibly L in Malay basin; and the fluvial Talang Akar formation in Sunda basin. Phase three was the brackish incursion, with brackish conditions developing in the Nam Con Son basin, and in the West Natuna and Malay basin lakes. Freshwater conditions, however, persisted in the Pattani, Kra and Khmer basins, and also those in northern Thailand. During this time, lacustrine deposition in southern Sunda, for instance in the Sunda basin of the West Java sea, was replaced by fluvial deposits with extensive coals of the Talang Akar formation. This succession is seen in Lower Dua formation of Nam Con Son, the Barat and Udang formations of West Natuna, and Seismic Group K in the Malay basin. 
The fourth phase witnessed the drowning of all fluvial and lacustrine sediments from West Java to Sumatra by marine transgression, and transformation of the Nam Con Son, West Natuna and Malay basins into normal salinity inland seas, although during this phase brackish lakes continued along the Khmer trough, and freshwater lakes persisted in parts of the gulf of Thailand and also in rifts to the North (Shoup et al., 2013).

The presence and extent of freshwater lakes is indicated by their content of algal microfossils (Fig. 5a). Algal palynomorphs attributed to Pediastrum, Botryococcus and extinct probable freshwater dinocysts such as Bosedinia and Granodiscus (Cole, 1992) (Figs. 6.12-13) are abundant in the lake deposits. The combined sum of Pediastrum, Bosedinia and Granodiscus often exceeds $95 \%$ of the total palynomorphs recorded over hundreds of metres of sedimentation, suggesting very large and long-lived lakes. On the basis of sedimentological restraints, it is thought that assemblages with abundant Bosedinia/Granodiscus reflect deeper water than assemblages in which Pediastrum is dominant, and from variations in the representation of Bosedinia/Granodiscus vs Pediastrum, cyclical variations in water depth are suggested. The continuous representation of abundant algal palynomorphs, repeated over periods in excess of $2 \mathrm{Ma}$ (e.g. for the Benua and Gabus Formations in West Natuna) emphasises the longevity of these lakes. The extinct genera Bosedinia and Granodiscus are reported widely in unpublished studies from the Sunda basin in the West Java sea to the gulf of Bohai in China. Of the dozen morphotypes described, most are restricted to the Oligocene and Late Eocene and form useful stratigraphic markers.

In later Late Oligocene, the incursion of brackish water is indicated by successive monospecific blooms of the agglutinated foraminifer Miliammina (Fig. 5a) accompanied by a general reduction in the representation of freshwater algae. The cyclical maxima of Miliammina sp. are thought to reflect $400 \mathrm{Ka}$ eccentricity cycles (Morley, 2012) based on comparisons of chronostratigraphy with cyclical patterns in $\mathrm{O}^{18}$ and $\mathrm{C}^{13}$ values in Western Pacific ocean drilling program (ODP) core 1218, reflecting the heartbeat of the Oligocene climate system (Palike et al., 2006).

\section{FRESHWATER SWAMPS OF THE SUNDA MID CENOZOIC}

Freshwater swamps of the sunda Mid Cenozoic can be divided into seasonally inundated swamps, fern swamps and alluvial and peat swamps as in the following paragraphs.

\section{Seasonally inundated swamps}

Palynomorph assemblages suggest swamps of both everwet climates, such as peat swamps, which will form only if the dry season is two months or less (Morley,
1982), and of seasonal climate swamps. The latter can be divided into Barringtonia, Brownlowia and Lagerstroemia swamps, grass/sedge swamps, and various fern swamps, summarised below.

\section{Barringtonia and Brownlowia swamps}

The distinctive prolate syncolpate pollen type Marginipollis concinnus Clarke and Fredriksen (1968), identical to Barringtonia calyptocalyx type pollen (Lecythidaceae) of Muller (1981), is often common in Upper Eocene and Lower Oligocene synrift deposits across the Sunda shelf, whereas in the Upper Oligocene it is common mainly in West Natuna successions. It is also common in fluvial successions in the North Malay (Tho Chu) basin during the Early Miocene. Today Barringtonia is a common element of beach forest, but it is also the commonest element of the seasonally flooded freshwater swamp of the Tonle Sap in Cambodia (Dy Phon, 1981). It is thought that the common occurrence of the Barringtonia calyptocalyx type pollen in Sunda shelf lacustrine facies (Fig. 6.7) indicates the former extensive development of seasonally inundated freshwater swamp forest around the lakes, in the same manner as seen in the present day seasonal swamp forests of Tonle Sap (Figs. 5b, 5c, 5d, 7a, 7b). Pollen studies from Tonle Sap by Penny (personal communication) suggest that Barringtonia is a low pollen producer, so that small changes in abundance of fossil Barringtonia pollen would suggest much bigger changes in abundance of Barringtonia in vegetation. The widespread occurrence of such assemblages from West Natuna to West Java strengthens the suggestion that Oligocene climates across Sundaland were distinctly seasonal (Morley, 2012).

Small numbers of Barringtonia pollen, especially if coming from marine deposits, may however be derived from coastal beach forest and from taxa such as Barringtonia asiatica. However, in some instances, Barringtonia pollen has been found abundantly in coals, from the Malay basin and Barito basin Early and Middle Miocene, and in such settings a different Barringtonia species, which could be peat-forming, could be the source. In Papua, widespread Barringtonia consocies occur on fluvial point bars, such as along the Mamberambo river (Shiel, personal communication). Coaly deposits with abundant Barringtonia pollen may reflect an origin from a similar source.

Pollen of the dispersed pollen type Discoidites novaguineensis Morley et al. (2001), identical to Brownlowia type pollen (Tiliaceae) (Fig. 6.9), is also common in the synrift deposits, and shows abundance fluctuations which relate closely to changes in abundance of freshwater algae (Fig. 5b), again suggesting derivation from a freshwater swamp source. Brownlowia, from a palynologist's viewpoint, is often seen as a backmangrove taxon (Muller, 1963), although it is very rare in backmangroves in, for instance the Malay peninsula (FRIM Mangrove Research 

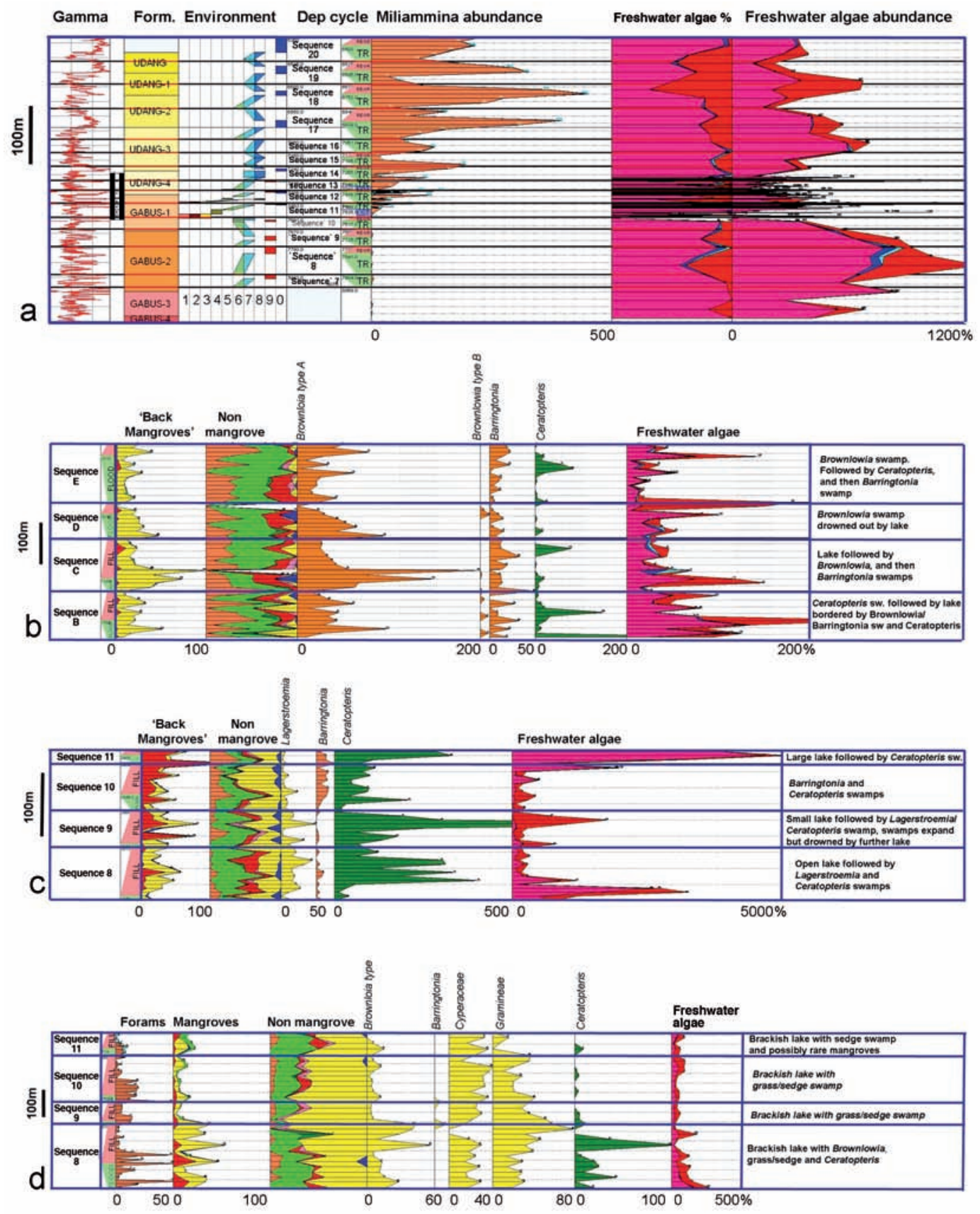

Fig. 5. a) North Belut-1 well, West Natuna basin, showing development phases 2 and 3 through the Oligocene Udang and Gabus (post rift) formations (Morley et al., 2007). Phase 2 is characterised by abundant freshwater algal palynomorphs suggesting an extensive lake, and phase 3 by the presence of pulses of the brackish foraminifer Miliammina, the latter occurring in cyclical pulses which are thought to tie to the 400 ka eccentricity cycles of Palike et al. (2006). For algal palynomorphs: deep red=Bosedinia/Granodiscus abundance; medium red=Pediastrum; and blue=spiny dinocysts. For environments: $1=$ =upper delta plain; $2=$ freshwater channel; $3=$ proximal lower delta plain; 4=brackish channel; $5=$ =mangrove flat; $6=$ distal lower delta plain; $7=$ proximal delta front; $8=$ distal delta front; $9=$ freshwater lake; $0=$ brackish lake. b) Diagram from phase 1, from the synrift of West Natuna (development phase 1, Lama/Benua formations). Interpreted sequences do not tie to any age scheme. c) Late Oligocene of Cuu Long basin (development phase 3, Bach Ho formation). Assemblages suggest swamps with abundant Lagerstroemia, Barringtonia and Ceratopteris. Interpreted sequences do not tie to any age scheme, age range. d) Brownlowia/grass/sedge swamps, Oligocene of West Natuna basin, development phase 3. Foraminifera consist exclusively of Miliammina spp. but with some contaminant calcareous benthonics in sequence 11 (contamination from cuttings samples). Interpreted sequences do not tie to any age scheme, age range $27 \mathrm{Ma}$ at base, $23 \mathrm{Ma}$ at top. For a), b), and c) ecological groups for pollen are: (back) mangroves (red=Acrostichum spores; yellow=backmangrove pollen; blue=Nypa; green=Rhizophora); non mangrove [brown=coastal; light green=mainly rain forest; dark green=kerapah (Dacrydium and Casuarina); red=peatswamp; pink=riparian; yellow=seasonal climate; blue=montane]. 
Group pers comm), where Brownlowia is also represented by several species of inland rain forests (Kochummen, 1973). Brownlowia type pollen also occurs in related genera such as the swamp tree Pentace and also Diplodiscus. Using Brownlowia systematically as a mangrove indicator is therefore misleading, and other factors need to be taken into account to determine the likely ecology of the parent plant of Brownlowia type pollen from Oligocene freshwater lake successions. A possibility is that the freshwater swamp tree Pentace was the contributor. In these settings, it probably contributes to the freshwater swamp vegetation based on its association with algal freshwater palynomorphs, and with Barringtonia, but perhaps in a more distal swamp setting than Barringtonia.

In The Early Miocene of the West Java sea and South Sumatra, Brownlowia pollen does occur commonly with mangrove pollen, but in greater morphological variety, together with the related taxon Discoidites pilosus (Venkatachala and Rawat, 1973) and it may indeed be sourced from a back mangrove setting.

\section{Lagerstroemia swamps}

In the Late Oligocene of the Cuu Long basin in southern Vietnam, Lagestroemia (Lythraceae) swamps were well developed, indicated by the common occurrence of Lagerstroemia pollen (Fig. 6.5), occurring together with Barringtonia and Brownlowia type pollen and also common Acrostichum spores. The abundance of Lagerstroemia pollen is suggestive of Myaing swamps (Yamada, 1998) of the Irawaddy in Myanmar (Fig. 5c).

\section{Grass/sedge swamps}

Grass and sedge pollen [Monoporopollenites annulatus, Van der Hammen (1954); Jaramillo and Dilcher (2001) (Fig. 6.8); and Cyperaceaepollis spp. (Fig. 6.6)] occurs abundantly especially in Late Oligocene sediments from West Natuna (Fig. 5d), and also eastern Penyu basin lakes, suggesting the widespread occurrence of Gramineae and Cyperaceae-dominated marshes surrounding those lakes. Grass and sedge pollen is also a common element in lacustrine and fluvial sediments from the Early Miocene of the northern Malay (Tho Chu) basin.

Today, grass-dominated swamps can be found along river courses in Borneo [e.g. in Sarawak, Beccarii (1904), and the Kutei lakes in East Kalimantan where they are considered to be of anthropogenic origin (Van Steenis, 1957)] and also behind the Songkla lakes in southern Thailand, where palynological analyses also demonstrate their anthropogenic origin. Extensive, grass-dominated swamps also occur in Tonle Sap, and along the Mekong river, where they have occurred without interruption since at least the beginning of the Holocene (Bishop et al., 2003) and hence are of entirely natural occurrence. Grass- dominated, often floating swamps are also well developed among the lowland swamps and lakes of the Fly river floodplain in Papua New Guinea (Rau and Reagan, 2009). The Tonle Sap, however, is seen as the best analogue for the grass/sedge-dominated swamps which surrounded the Late Oligocene West Natuna and Penyu lakes, and also the Tho Chu lakes during the Early Miocene. In the same manner as Barringtonia swamps, grass/sedge swamps appear to be strongly controlled by climate, occurring only in areas characterised by distinctly seasonal climates.

\section{Fern swamps}

Fern spores are particularly abundant in some lacustrine and fluvial successions, especially within the late synrift Mid Oligocene succession, and also the Tho Chu basin and Pattani trough Early Miocene, where fern spores sometimes overwhelmingly dominate palynomorph assemblages to the virtual exclusion of angiosperm pollen (see below). Two spore types, the dispersed spore Magnastriatites grandiosus (Kedves and Sole de Porta, 1963; Duenas, 1986) (Fig. 6.11), derived from the aquatic fern Ceratopteris (Parkeriaceae), and Verrucatosporites usmensis (Van der Hammen, 1954), derived from the climbing fern Stenochlaena palustris (Blechnaceae) (Fig. 6.2), are particularly common, and in both instances are thought to contribute to freshwater marshes and possibly floating vegetation mats.

\section{Ceratopteris swamps}

Spores attributable to Magnastriatites grandiosus are sometimes extremely abundant, with abundances determined by age and latitude, and hence climate. Thus, they are commonly seen in Oligocene sediments, deposited when seasonal climates were widespread, from West Java to Vietnam, but in the Early Miocene, when everwet climates became predominant across much of the Sunda shelf, they tend to be abundant only in the more northerly basins of Tho Chu, Pattani and Cuu Long. The spores rarely occur in high abundances after the Middle Miocene.

Ceratopteris thalictroides, the typical species in Southeast Asia, is a low, aquatic fern, which can grow either as a perennial or as an annual. It is apparently the only aquatic fern which can grow under a tree canopy. It is infrequent in the region today, except sometimes as a weed of rice fields and is often grown commercially as an aquarium plant. Despite extensive search, the authors have never found Ceratopteris growing in the abundances suggested by its mid Cenozoic spore record. The only description of a swamp with dominant Ceratopteris thalictroides, which might fit with the abundances seen in the fossil record, is from Hisiu Lagoon, a series of muddy, seasonally flooded lakes forming behind beach ridges on the southern margin of the Huon peninsula in Papua New Guinea (Osbourne, 1996) These lakes occur in an area of 

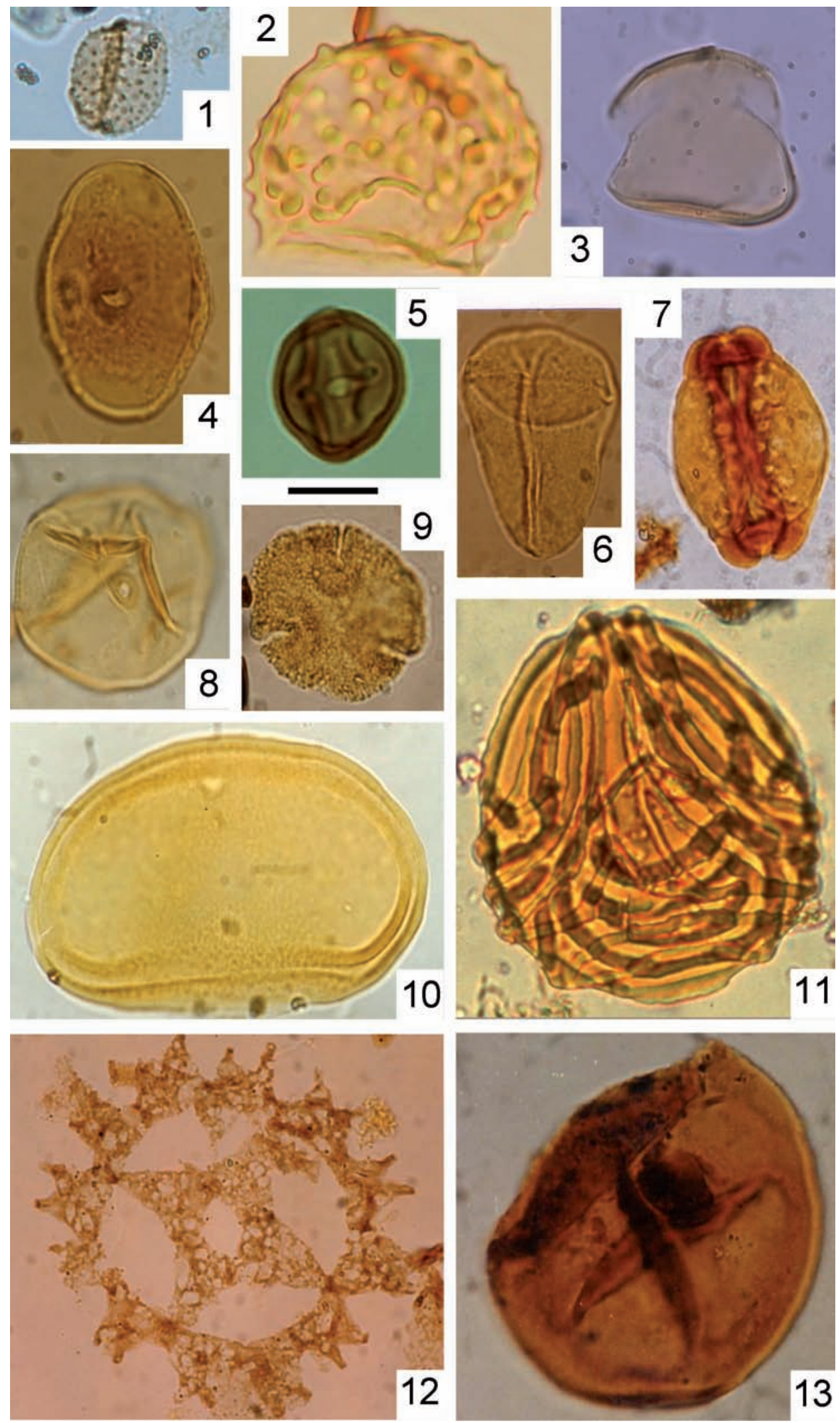

Fig. 6. Pollen of common swamp taxa: 1 Pandaniidites sp.; 2, Verrucatosporites usmensis; 3, Dicolpopollis sp.; 4, Florschuetzia levipoli; 5, Lagerstroemia type; 6, Cyperaceaepollis sp.; 7, Marginipollis concinnus; 8, Monoporopollenites annulatus; 9, Discoidites novaguineensis; 10, Laevigatosporites sp.; 11, Magnastriatites grandiosus; 12, Pediastrum bifidites; 13, Granodiscus sp. Bar approx 10 micron. 
seasonal climate, experiencing a five month wet season, and characterised by monsoon forest and savanna grassland. The lakes periodically dry out during the dry season. Despite its distance from the Sunda shelf, this location may well form a good analogue.

Examination of the distribution of Ceratopteris spores relative to algal palynomorphs suggests that the parent plant generally grew in shallow lakes and on swamps; abundance trends sometimes following algal abundances and sometimes being offset within a depositional cycle (Fig. 5b, 5c, 5d), suggesting the possibility of a combination of rooted swamps and floating mats. The spores are also very common in successions shown by sedimentology to form overbank deposits. It is suggested that $\mathrm{Cer}$ atopteris may also form annual blooms in seasonally flooded lakes, hence its particularly common occurrence in areas of seasonal climate.

Intervals with common Ceratopteris spores also often yield common pollen of the pondweed Potomogeton (Potomogetonaceae), and also Merremia (Leguminosae), a scrambling climber common today on herbaceous swamps across the region.

\section{Stenochlaena swamps}

The dispersed spore taxon Verrucatosporites usmensis is a common element of most palynomorph assemblages from the Middle Eocene onward, but becomes an abundant, or superabundant element only from the earliest Miocene onward. It is found in particularly high abundances in proximal settings from the Penyu basin northward, and especially in the Tho Chu basin (Fig 7a). The parent plant is a climbing fern, and is common especially in open swamp forest communities, but can occur commonly in most areas with open or disturbed vegetation other than mangroves. When peat swamp forests are clearfelled, a herbaceous swamp consocies of Stenochlaena palustris often forms the first stage of regrowth.

The huge abundances of Stenochlaena palustris spores seen in the abovementioned basins is therefore thought to reflect poorly drained fluvial plain settings in which peat swamps did not develop, probably due to insufficient year-round moisture availability to enable peat swamps to form. Sometimes the maxima of S. palustris spores coincide with increased abundances of peat swamp pollen, perhaps suggesting open peat swamp forest festooned with S. palustris. Sometimes acmes of S. palustris spores occur at the base of coals, suggesting that $S$. palustris thickets formed the initial stage of vegetation cover before the establishment of peat swamp forest.

\section{Undifferentiated fern swamps}

Many ferns, especially the leptosporangiate group which includes such families as Thelypteridaceae (with many terrestrial swamp ferns) and epiphytic Aspleniaceae, produce monolete (bean shaped) spores which comprise an inner laevigate (smooth) body without ornamentation, and an outer, loosely attached perine, which is often strongly ornamented, and on which basis it is often possible to identify a fern to the species (Nayar and Devi, 1964a, 1964b, 1964c). However, on fossilisation, the outer perine is generally lost, leaving only the indeterminate smooth bean-shaped spore as a prominent component of many palynomorph assemblages (Fig. 6.10). Anderson and Muller (1975) interpreted the laevigate spores seen in a Middle Miocene coal as Asplenium type, because Asplenium spp. were common in present day peat swamp forests in Sarawak and Brunei, and this has led a generation of younger palynologists to consider all such spores from the Sunda region as Asplenium, whereas in reality they could be derived from a great variety of different taxa. It is likely that members of the Thelypteridaceae, with many species occurring in swamps, and epiphytic Polypodiaceae, could also be major contributors to this spore group.

Smooth monolete and trilete spores, the latter sometimes with weak ornamentation, form a distinct maximum within the mid-Oligocene (Fig. 7b), at the end of the synrift phase of the West Natuna basin and adjacent areas, suggesting widespread fern-dominated vegetation at this time, probably occurring in ephemeral fluvial swamps. Sometimes these assemblages contain common weakly ornamented trilete spores suggesting the swamp fern $O S$ munda. The early postglacial palynomorph assemblages described from core 19,300 from the South China sea, offshore Natuna island by Wang et al. (2009), show a similar spore acme, suggesting that fern swamps may have been prominent elements of the short-lived freshwater swamps which formed widely across the Sunda shelf after the shelf was flooded by the post glacial transgression (Cannon et al., 2009).

\section{Alluvial and peat swamps}

The history of both basinal peat swamps and kerapah swamps is discussed elsewhere (Morley, 2013). Basinal peat swamps became common around the Early Miocene inland sea, coinciding with the development of everwet climates across Sundaland (Morley, 2012) and they expanded northward into the gulf of Thailand at the time of the Middle Miocene thermal maximum. Kerapah swamps first became widespread in the West Java sea coaly Talang Akar formation, during the Late Oligocene (Lelono and Morley, 2011). The characteristic kerapah elements (Dacrydium associated with Casuarina type pollen) also occurred in successive cycles during the Early Miocene around the Malay basin and West Natuna inland sea. Cycles of these palynomorphs are useful in delineating depositional sequences during the Early Miocene in this 
area, since kerapah swamps are thought to develop mostly during the early transgressive phase of a sea level cycle (Morley, 2013).

There are few floristic differences between many freshwater alluvial swamps and basinal peat swamps, as emphasised by Corner (1978) who found the same species growing on the alluvial non-peat forming swamps along the Sedili river in Johore, West Malaysia, as were present in the peat swamps South of Pekan, just to the North. The occurrence of common pollen of taxa typical of peat swamps, but without indications of peat accumulation (as coals), and within a fluvial depositional setting, may suggest the former presence of alluvial swamp forest. Such situations would have frequently occurred during the Natuna and Malay basin in Early Miocene.

\section{Pandanus swamps}

The small, monoporate echinate, weakly annulate pollen of Pandanus, described as the dispersed taxon Pandaniidites spp. (Fig. 6.1), but rarely speciated, is commonly found as a background element in most Oligo-Miocene palynomorph assemblages from the region, but sometimes it is found in great abundance, overwhelmingly dominating assemblages, in which case it is thought to reflect the occurrence of former Pandanusdominated swamps (Fig. 7a and 7c). The areas in which Pandanus pollen shows these great abundances are limited to the proximal margins of some of the more proximal basins, in particular, the Penyu basin, during Early Miocene (Fig. 7a), which straddles between Malaysian and Indonesian offshore territories to the West of the southern Malay peninsula, the Malay basin, and also in proximal localities in Middle Miocene of the Pattani basin in the gulf of Thailand (Fig. 7c).

Pandanus-dominated swamps occur today in the Malay peninsula, at Tasek Bera and Tasek Chini, which are rheotrophic swamps occurring in drowned river systems adjacent to the Pahang river, and in the Kapuas lakes area in West Kalimantan (Corner, 1978). The Tasek Bera swamps have been studied both ecologically (Lim et al., 1982) and palynologically (Morley, 1981a, 1981b, 1982) and are believed to be maintained as a result of pronounced annual flooding, which apparently inhibits the development of peat swamp forest, with the result that such swamps are overwhelmingly dominated by the stiltrooted Pandanus helicopus. Palynomorph assemblages from Tasek Bera are mostly characterised by Pandanus pollen values of $90 \%$ or more (Morley, 1982).

In the Penyu basin, Intervals with abundant Pandanus pollen occur between an interval with abundant Stenochlaena palustris spores, and one with common peat swamp pollen. These suggest a prolonged period of everwet climate but without peatswamp development, and so perhaps the Pandanus swamps were maintained by pro- nounced annual flooding, as with Tasek Bera today. The Pandanus-rich assemblages from the Middle Miocene of the Pattani trough are otherwise associated with grass pollen maxima, and the suggestion here is that pronounced annual flooding was maintaining the domination of Pandanus, but within an area of more seasonal climate, as suggested by the common occurrence of Gramineae pollen. There seems to be a succession in this area from Pandanus, through Gramineae swamps, to freshwater lake facies.

\section{Rattan swamps}

Rattan pollen (Dicolpopollis spp., derived from Calamus and Daemonorops, Palmae), is a very common element of Sunda Miocene pollen assemblages (Fig. 6.3). It is also sometimes abundant in coals, especially those with a significant mud content. Today rattans are infrequent elements of basinal or kerapah peat swamps, but do occur commonly in the Berbak swamp in South Sumatra, which is a rheotrophic, as opposed to an ombrotrophic swamp as in the case of basinal and kerapah peats (Morley, 2013). Rattans are also prominent in swamps in areas of seasonal climate, such as Central Java, Myanmar and eastern Sulawesi. Rattan swamps, therefore, suggest marginal settings, especially for peat formation. Rattan swamps were probably very common in the Late Oligocene and Early Miocene, possibly under marginally seasonal climates, but became less common from the Middle Miocene onward as basinal peats became more widespread.

\section{MANGROVE SWAMPS}

Mangroves are plants which have specially adapted to tolerate saline water, and occur around most tropical coastlines, particularly where the substrate is mud. They are included in this discussion firstly since, although most require brackish water in which becoming established, many continue to grow following delta progradation in fully freshwater settings, particularly if still within the reaches of tidal influence; and secondly, because their relationship to fluvial coastal plain communities need to be understood in order to visualise succession of freshwater ecosystems in relation to sea level change and coastal progradation. Mangrove ecology is determined mainly by degrees of tidal inundation, rather than salinity, followed by salinity variations, a conclusion recently verified by studies of Malaysian mangroves of contrasting delta systems (Yakzan et al., 2010).

\section{Rhizophora swamps}

Rhizophora swamps occur at the distal margin of a delta or coastline, and are widely developed on the brackish lower delta plain in areas subject to the most frequent 

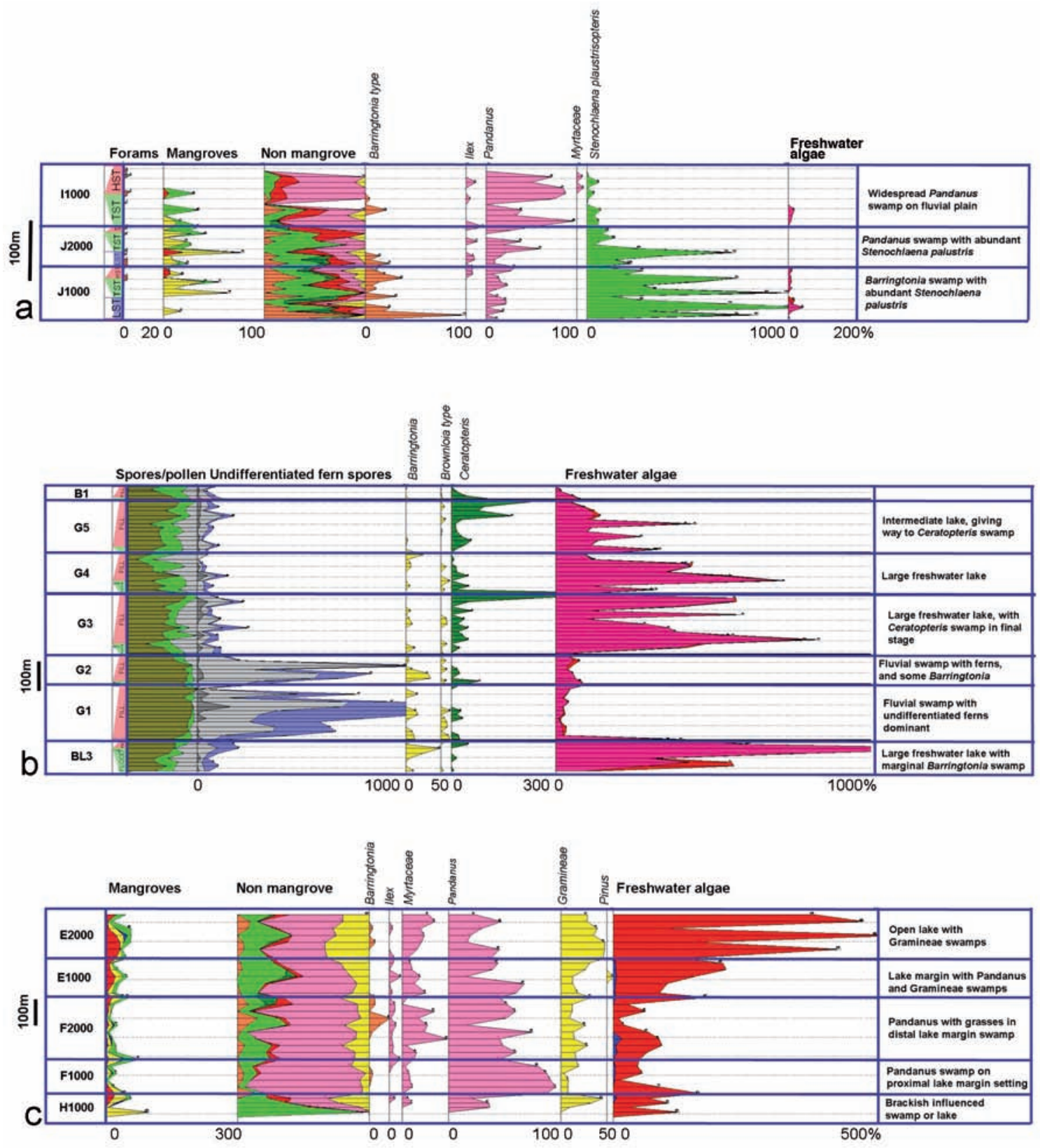

Fig. 7. a) Stenochlaena and Pandanus swamps in Penyu basin, Early Miocene, development phase 4. Foraminifera include scattered agglutinated and calcareous benthonic taxa, for mangrove groups see Fig. 8, for ecological groups see Fig. 5. Base sequence J1000, 23.0 Ma; base sequence I1000, 21.8 Ma. b) Fern swamps in the Oligocene synrift (development phase 1) and postrift (development phase 2) of West Natuna basin. For undifferentiated fern spores, dark grey=verrucate monolete; light grey=smooth monolete; and blue $=$ smooth trilete. For the spores/pollen ratio, dark green=spores; light green=identified pollen; and grey=poorly preserved unidentified pollen. For algal palynomorph groups see Fig. 5, base sequence BL3, 34 Ma; base G4, 29.5 Ma; base B1 27.5 Ma. c) Pandanus swamps from Pattani trough, gulf of Thailand Middle Miocene, development phase 4. For ecological explanation of groups see Fig. 5, base H2000, 14.6 Ma; base F1000, 14.2 Ma; base E11000 13.7 Ma. For a) and c) ecological groups for pollen are: mangroves (red=Acrostichum spores; yellow=backmangrove pollen; blue=Nypa; green=Rhizophora); non mangrove [brown=coastal; light green=mainly rain forest; dark green=kerapah (Dacrydium and Casuarina); red=peatswamp; pink=riparian; yellow=seasonal climate; blue=montane]. 
tidal inundation where salinities vary from 10 to $35 \%$. They are dominated by the genus Rhizophora (Rhizophoraceae), and often by Sonneratia alba (Sonneratiaceae) with other genera of Rhizophoraceae, such as Bruguiera, Kandelia and Ceriops, occurring in areas with reduced tidal flooding. Pollen records from Late Quaternary deposits indicate that the Rhizophoraceae tend to be more common at times of rising sea levels during transgressive episodes, than at times of sea level stillstand and delta progradation (Morley, 1996; Morley et al., 2004; Grindrod et al., 2001).

\section{Nypa swamps}

Nypa (Palmae) swamps occur in two settings, either lining brackish rivers, where salinites are less than 10 to $15 \%$, such as along the Langat and Sedili rivers in West Malaysia, or as a consocies on the fresh to brackish delta plain, as in the case of the Bornean Mahakam and Rajang deltas, where salinites have not been recorded. Surprising results of a recent study from the Langkat river system in West Malaysia (Mahani Mohamed et al., 2011) indicate that Nypa swamps extend from the zone of brackish salinities far into the freshwater zone, but still within the tidal limit.

\section{Sonneratia caseolaris swamps}

Sonneratia caseolaris is a widespread backmangrove tree, which usually lines tidal rivers where Nypa is dominant, such as on the Mahakam delta in Borneo and Sedili river in West Malaysia. In the Langkat river system in West Malaysia, Sonneratia caseolaris first appeared commonly when salinities were about $0 \%$, and continued, like the commonest mangrove species, until the tidal limit, thus characterising the freshwater intertidal zone in that river system. The common occurrence of $S$. caseolaris pollen may thus reflect environments where salinities are low or negligible, but the influence of tides remains significant.

In Miocene successions, Florschuetzia levipoli (Germeraad et al., 1968), the dispersed pollen from Sonneratia caseolaris (Fig. 6.4), is often exceedingly abundant, suggesting that Sonneratia caseolaris swamps were much more widespread at that time than at present. A possible explanation of these abundances is that in the partially enclosed seas of Sunda shelf, large areas may have been within the reach of tidal activity, but due to the distances from fully marine environments, they may have been characterised by low or negligible salinities. The genus Sonneratia is thought to have evolved from Lythraceous ancestors allied to Lagerstroemia (Muller, 1981) during the Early Miocene, with Sonneratia caseolaris appearing at about $22 \mathrm{Ma}$, just as the inland seas of the northern Sunda shelf were becoming established, and this leads to suggest that it was this unusual habitat which led to the evolution of the genus Sonneratia.

\section{SUCCESSIONS}

The swamp communities described above often occur in association, depending on a combination of regional geography and climate, and succession within aggrading or prograding deltas or coastal plains. Associations suggest five main successional scenarios, depending on salinity of the adjacent water body (lake or inland sea) regional climate, age, and the degree of seasonal flooding (Fig. 8).

The primary factor is probably marine connectivity of the adjacent water body. All the strictly lacustrine successions studied occurred in areas of seasonal climate, as is generally the case for low latitude lakes. In most instances the lakes would have been subject to seasonal flooding, like in present day Tonle Sap. More proximal areas, or areas with less pronounced annual flooding, would have been characterised by Barringtonia swamps, and with increased flooding these would have been replaced by Brownlowia swamps and then with grass/sedge swamps, possibly floating, adjacent to the lake. Ceratopteris mats and floating aquatics such as Potamogeton could have been associated with each of these communities, probably depending on the degree of annual flooding and drying (Fig. 8.1). Age may be a factor as well, since, although Barringtonia swamps have been recorded from all the time periods under discussion, Pandanus swamps associated with lakes are known only from the Middle Miocene (Fig. 8.2).

With the development of low salinity inland seas, regional climate formed a major control, inhibiting peat swamp development in areas of seasonal climate. In areas of marginally seasonal climate, fluvial plains tended to bear rattan and Stenochlaena swamps, perhaps with a few scattered peatswamp elements. During periods when such swamps were widespread, Sonneratioid swamps, with the parent plant of Florschuetzia trilobata as a dominant element, were particularly common along shorelines (Fig. 8.3).

In areas of everwet climate and normal salinity inland seas, tree-dominated swamps were more the rule, but again, annual flooding is thought to have been a major control on swamp communities, and where this is pronounced, it inhibited peat swamp formation with the result that alluvial and Pandanus swamps may have become widespread behind the mangrove belt, perhaps with open swamps with Stenochlaena palustris between (Fig. 8.4).

On the contrary, where seasonal flooding is reduced, in areas of true equatorial climate, basinal peat swamp growth took over across upper coastal plains, as is the case for the present day sea level highstand across much of the Sunda shelf (Fig. 8.5).

\section{CONCLUSIONS}

Freshwater wetlands were much more extensive during the mid Cenozoic than today due to the presence of 
very widespread deep freshwater lakes in deep tectonic depressions across the region, of which Tonle Sap in Cambodia is the only present day analogue. This has resulted in mid Cenozoic freshwater wetlands being very different from present day wetlands (Fig. 9).

Deep inland freshwater lakes were at their greatest extent within the Early Oligocene and early part of the Late Oligocene, after which time they were largely replaced by brackish lakes, and then by near-normal salinity, partially enclosed inland seas. Seasonal climate swamps, dominated by Barringtonia, Brownlowia, Lagerstroemia and grasses/sedges were very prominent during this time. Fern swamps were widespread during the Oligocene and Miocene, Ceratopteris being an important component, probably reflecting pronounced seasonal flooding; on the contrary, peat swamps began to develop in the late Oligocene of southern Sunda, with kerapah type peats developing in Java sea region. Basinal peat swamps became widespread from the Early Miocene onward, probably replacing rattan-dominated swamps, and with their greatest development probably during the Early and Late Miocene.

This review indicates the longevity of many wetland ecosystems and this has important implications with respect to conservation across the region. Seasonally-inundated freshwater swamp forests dominated by Barringtonia spp. have a history extending back to the Late Eocene. This ecosystem occurs today only in Tonle Sap in Cambodia, where its maintenance is severely threatened from drainage and development. Kerapah-type ombrotrophic mires have been continuously present in the region since at least the Late Oligocene, but their current occurrences in Borneo are severely threatened. Lagerstroemia swamps, dating also from the Late Oligocene, occur today only on the severely threatened Irawaddy floodplain. The last remaining extensive rattan swamps are now probably restricted to the threatened Berbak swamp in Sumatra. Hopefully, bringing to attention the antiquity of the wetland ecosytems across Southeast Asia will add additional justification to encourage their conservation.

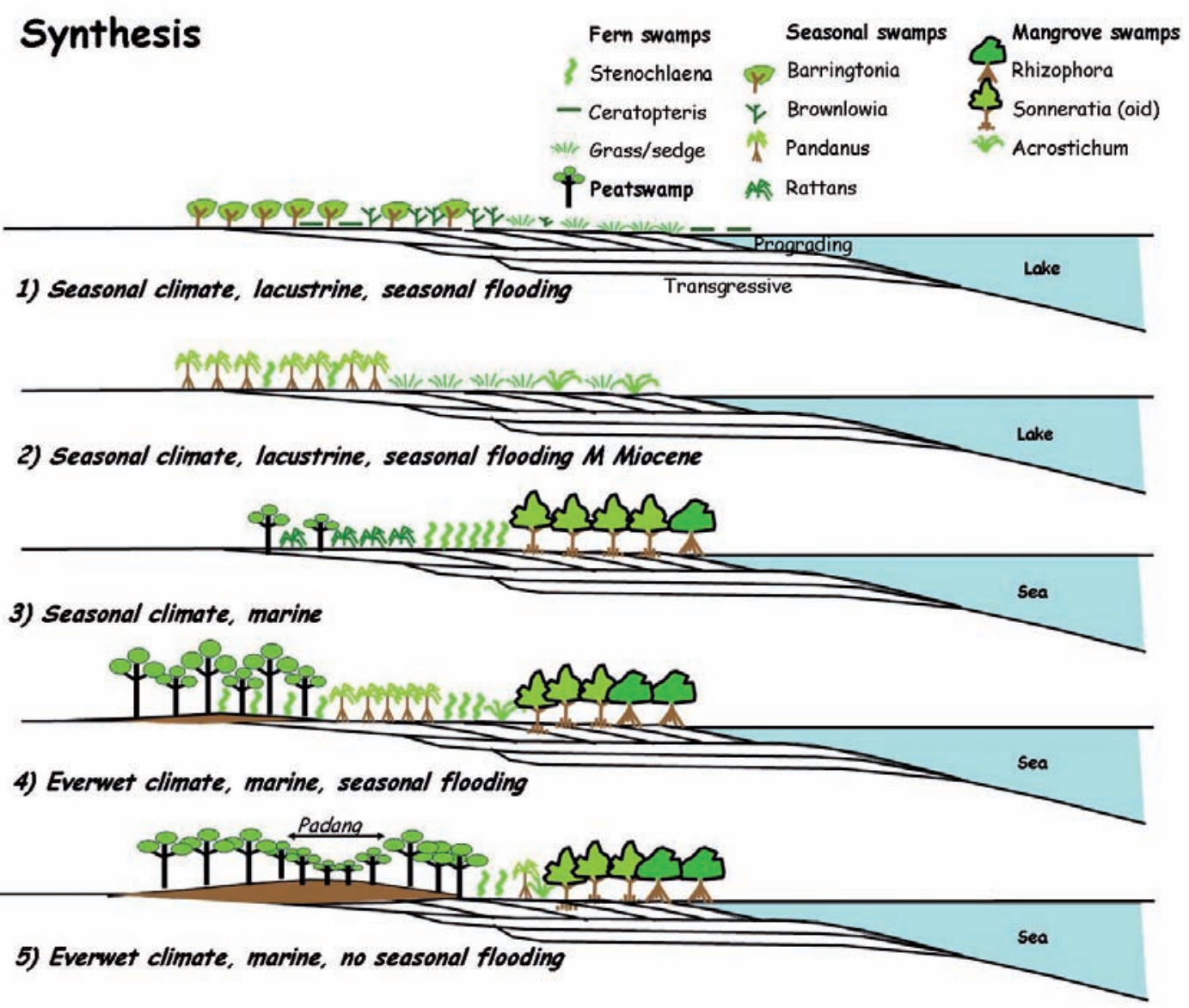

Fig. 8. Suggested successions within Sunda shelf Cenozoic lakes and inland seas. 


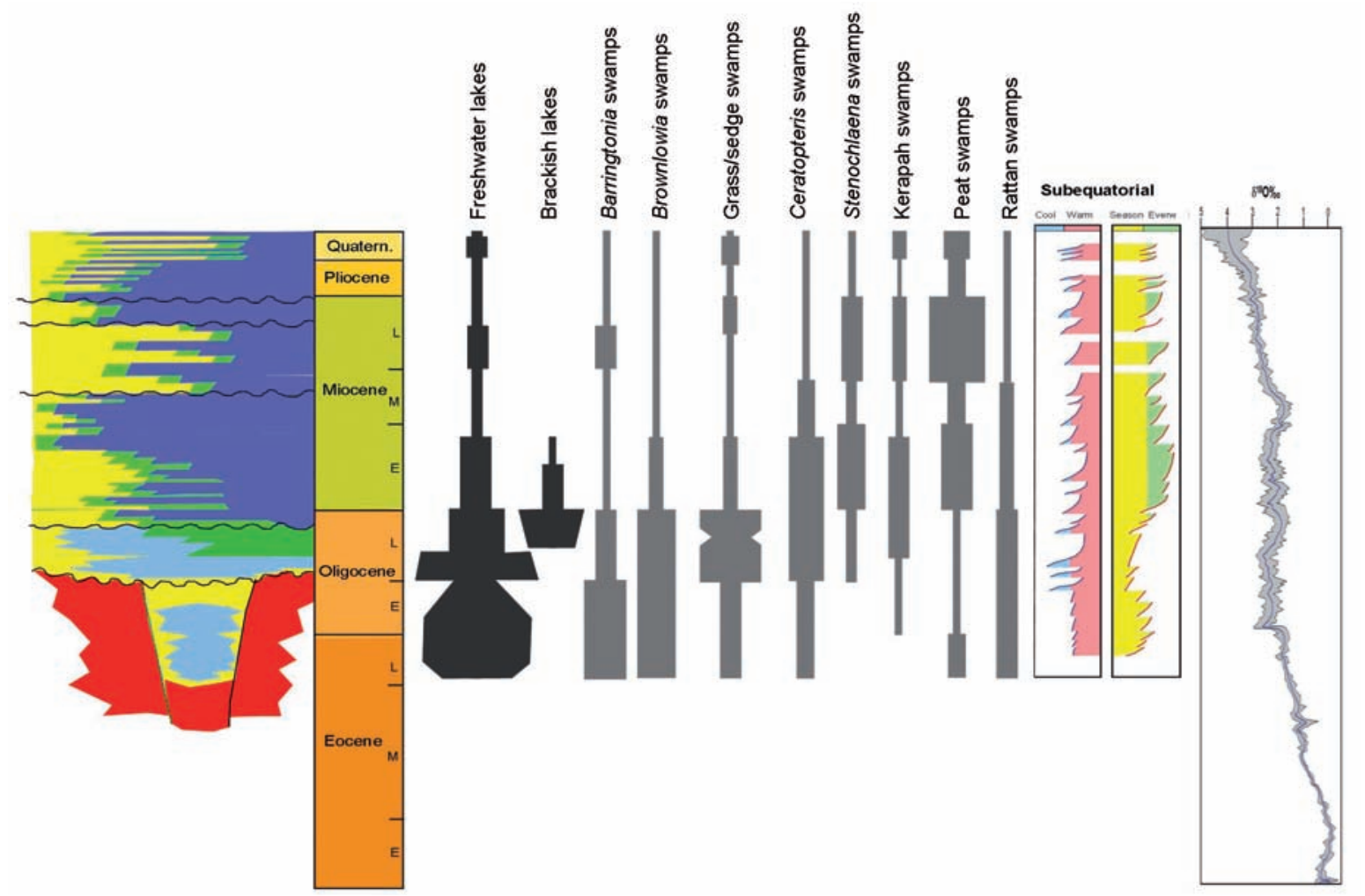

Fig. 9. Summary of Sunda shelf extent freshwater swamp ecosystems during the Tertiary period. The width of each vertical column approximately reflects the representation of each swamp type through time, but are not to scale. Climate trends modified after Morley (2012), $\partial^{18}$ O curve from Zachos et al. (2008). Red=basement; yellow=fluvial; light blue=freshwater lacustrine; dark green=brackish lake; dark blue= normal marine; light green=mangrove swamps

\section{ACKNOWLEDGMENTS}

This paper is based on a database which has been generated by many different palynologists over many years. To them acknowledgment is made, although interpretations of wetland systems are wholly due to the Authors. The Authors would also like to thank to organisers of the 2012 FISA Conference, Prof. La-orsri Sanoamuang and Dr. Maria K. Hołyńska for inviting us to the Mahasarakam workshop in Thailand, prompting the writing of this paper, and also to Dr. Kay Van Damme for inviting to contribute to the proceedings. The reviewers, Robert Hall, Carlos Jamarillo and John Flenley, and also the editor Kay Van Damme, greatly improved the text and especially encouraged expansion of the discussion of the similarities to the East African lakes. An early version of this paper was originally presented at the 2010 Flora Malesiana meeting in Singapore, organised by Benito Tan.

\section{REFERENCES}

Anderson JAR, Muller J, 1975. Palynological study of a Holocene peat and a Miocene coal deposit from N.W. Borneo. Rev. Palaeobot. Palyno. 19:291-351.

Baker BH, Wohlenberg J, 1971. Structure and evolution of the Kenya Rift Valley. Nature 229:538-542.

Beccari O, 1904. Wanderings in the great forests of Borneo. Oxford University Press, Oxford: $424 \mathrm{pp}$.

Bishop P, Penny D, Stark M, Scott M, 2003. A 3.5 ka record of palaeoenvironments and human occupation at Ankor Borei, Mahakam Delta, Southern Cambodia. Geoarchaeology 18:353-393.

Briais A, Patriat P, Tapponier P, 1993. Updated interpretation of magnetic anomalies and sea floor spreading stages in the South China Sea: implications for the Tertiary tectonics of SE Asia. J. Geophys. Res. 98:6299-6328.

Cannon CH, Morley RJ, Bush ABG, 2009. The current refugial rainforests of Sundaland are unrepresentative of their biogeographic past and highly vulnerable to disturbance. P. Natl. Acad. Sci. USA 106:11188-11193. 
Chaimanee Y, Jarger J-J, Suteethorn V, Ducrocq S, 1997. A new Late Eocene anthropoid primate from Thailand. Nature 385:429-431.

Clarke RT, Fredriksen NO, 1968. Some new sporomorphs from the Upper Tertiary of Nigeria. Grana 3:544-546.

Cole JM, 1992. Freshwater dinoflagellate cysts and acritarchs from Neogene and Oligocene sediments of the South China Sea and adjacent areas, p. 181-196. In: J.M. Head and J.H. Wrenn (eds.), Neogene and Quaternary dinoflagellate cysts and Acritarchs. American Association of Stratigraphic Palynologists Foundation ed.

Cole JM, Crittenden S, 1997. Early Tertiary basin formation and the development of lacustrine and quasi-lacustrine/marine source rocks of the Sunda Shelf of SE Asia, p. 147-184. In: A.J. Fraser, S.J. Matthews, and R.W. Murphy (eds.), Petroleum geology of Southeast Asia. Geological Society Publ.

Corner EJH, 1978. The freshwater swamp-forest of South Johore and Singapore. Botanic Gardens ed., Singapore: 266 pp.

Ducrocq S, Chaimanee Y, Suteethorn V, Jaeger J-J, 1998. The earliest known pig from the upper Eocene of Thailand. Palaeontology 41:141-156.

Duenas H, 1986. [Geologia y palinologia de la formacion cienaga de Oro. Region Caribe Colombiana]. [Thesis in Spanish]. Ministerio de Minas y Energía, Instituto Nacional de Investigaciones Geologico-Mineras Publ., Bogotá: 51 pp.

Dy Phon, P 1981. [Contribution à l'étude de la végétation du Cambodge]. [PhD Thesis in French]. Université de ParisSud ed., Orsay: 252 pp.

Germeraad JH, Hopping CA, Muller J, 1968. Palynology of tertiary sediments for tropical areas. Rev. Palaeobot. Palynolo. 6:189-348.

Ginger DC, Ardjakusamah WO, Hedley RJ, Pothecary J, 1993. Inversion history of the West Natuna Basin: examples from the Cumi-Cumi PSC. Proc. of the $22^{\text {nd }}$ Annu. Conv. Indonesian Petroleum Association 1:635-658.

Grindrod J, Moss P, van der Kaars S, 2001. Late Quaternary cycles of mangrove development and decline on the north Australian continental shelf. J. Quaternary Sci. 14:465-470.

Hall R, 2002. Cenozoic geological and plate tectonic evolution of SE Asia and the SW Pacific: computer-based reconstructions, model and animations. J. Asian Earth Sci. 20:353-431.

Hall R, 2012. Sundaland and Wallacea, geology, plate tectonics and palaeogeography, p. 32-78. In: D. Gower, K. Johnson, J. Richardson, B. Rosen, L. Rüber, and S. Williams (eds.), Biotic evolution and environmental change in Southeast Asia. Cambridge University Press.

Hall R, Morley CK, 2004. Sundaland basins, p. 55-85. In: P. Clift, P. Wang, W. Kuhnt, and D.E. Hayes (eds.), Continentocean interactions within the East Asian marginal seas. American Geophysical Union ed.

Jaramillo C, Dilcher DL, 2001. Middle Palaeogene palynology of Central Colombia, South America. A study of pollen and spores from tropical latitudes. Palaeontogr. Abt. B 285:87-213.

Katz BJ, Kelly PA, 1987. Central Sumatra and the East African rift lake sediments: an organic geochemical comparison. Proc. of the $16^{\text {th }}$ Annu. Conv. Indonesian Petroleum Association 1:259-289.

Kedves M, Sole de Porta N, 1963.[Comparación de las esporas del género Cicatricosisporites R. Pot. Y Gell. 1933 de Hungría y Colombia. Algunos problemas referente a su significado estratigráfico]. [Article in Spanish]. Boletín de Geología de la UIS 12:51-76.
Kochummen, KM, 1973. Tiliaceae, p. 492-513. In: T.C. Whitmore (ed.), Tree flora of Malaya. Longman.

Lelono EB, Morley RJ, 2011. Oligocene palynological succession from the East Java Sea, p. 333-345. In: R. Hall and M. Wilson (eds.), Southeast Asian gateway evolution. Geological Society of London Publ.

Lim RP, Furtado JI, Morley RJ, 1982. General description of Tasek Bera, p. 7-11. In: J.I. Furtado and S. Mori (eds.), Tasek Bera, the ecology of a freshwater swamp. Springer.

Leong KM, 1999. The petroleum geology and resources of Malaysia. Petronas Publ., Kuala Lumpur: 665 pp.

Mahani M, Shamsuddin J, Sanatul SH, 2011. Salinity stratification and its effects on the Malay Basin biofacies assemblages. Petroleum Geoscience Group, University of Malaysia Publ., Kuala Lumpur.

McGregor D, 2012. The progressive development od the East African rift systems and its impact on petroleum systems. Surestream Petroleum Publ., Reading. Available from: http://www.surestream-petroleum.com/USERFILES/FILE/ THE\%20PROGRESSIVE\%20DEVELOPMENT\%20OF\%2 0 THE $\% 20$ EAST $\% 20$ AFRICAN $\% 20$ RIFT\%20SYSTEM $\% 20 A N D \% 20 I T S \% 20 I M P A C T \% 20 O N \% 20$ PETROLEUM\%20SYSTEMS\%20BY\%20DR\%20DUNCAN\%20 MACGREGOR.PDF

Morley RJ, 1977. Palynology of Tertiary and Quaternary sediments in southeast Asia. Proc. of the $6^{\text {th }}$ Annu. Conv. Indonesian Petroleum Association 1:255-276.

Morley RJ, 1981a. Development and vegetation dynamics of a lowland ombrogenous swamp in Kalimantan Tengah, Indonesia. J. Biogeogr. 8:383-404.

Morley RJ, 1981b. Palaeoecology of Tasek Bera, a lowland swamp in Pahang, West Malaysia. Singapore J. Trop. Geo. 2:50-56.

Morley RJ, 1982. The origin and history of Tasek Bera. In: J.I. Furtado and R.P. Lim (eds.), The ecology of a tropical freshwater swamp, the Tasek Bera, with special reference to biological production. Junk Publ., The Hague.

Morley RJ, 1991. Tertiary stratigraphic palynology in South-East Asia. Current status and new directions. Bull. Geol. Soc. Malaysia 28:1-36.

Morley RJ, 1996. Biostratigraphic characterisation of systems tracts in Tertiary sedimentary basins. Proc. of the Symposium on Sequence Stratigraphy in SE Asia, pp. 49-70.

Morley RJ, 1998. Palynological evidence for Tertiary plant dispersals in the SE Asia region in relation to plate tectonics and climate, p. 177-200. In: R. Hall and J. Holloway (eds.), Biogeography and geological evolution of SE Asia. Bakhuys Publ.

Morley RJ, 2000. Origin and evolution of tropical rain forests. Wiley \& Sons, London: 362 pp.

Morley RJ, 2006. Cretaceous and Tertiary climate change and the past distribution of megathermal rain forests, p. 1-26. In: M. Bush and J.R. Flenley (eds.), Tropical rainforest responses to climatic change. Praxis-Springer.

Morley RJ, 2012. A review of the Cenozoic palaeoclimate history of Southeast Asia, p. 79-114. In: D.J. Gower, K.G. Johnson, J.E. Richardson, B.R. Rosen, L. Rüber, S.T. Williams (eds.), Biotic evolution and Environmental change in SE Asia. Cambridge University Press.

Morley RJ, 2013. Cenozoic ecological history of Southeast Asian peat mires based on comparison of coals with present day and Late Quaternary peats. J. Limnol. 72(s2):eXXX. 
Morley RJ, Lelono EB, Nugrahaningsih L, Hasjim N, 2001. LEMIGAS Tertiary palynology project: aims, progress and preliminary results from the Middle Eocene to Pliocene of Sumatra and Java, p. 27-47. In: Geological Research and Developmental Centre (ed.), Environmental photochemistry. Geological Research and Developmental Centre.

Morley RJ, Morley HP, Restrepo-Pace P, 2003. Unraveling the tectonically controlled stratigraphy of the West Natuna Basin by means of palaeo-derived Mid Tertiary climate changes. Proc. of the $29^{\text {th }}$ Annu. Conv. Indonesian Petroleum Association 1:1-24.

Morley RJ, Morley HP, Wonders AA, Sukarno HW, van der Kaars S, 2004. Biostratigraphy of modern (Holocene and Late Pleistocene) sediment cores from Makassar straits, $\mathrm{p}$. 361-371. In: Proc. Symp. Deepwater and Frontier exploration in Asia \& Australasia, Jakarta, 2004.

Morley RJ, Swiecicki T, Thuy Thi Pham D, 2011. A sequence stratigraphic framework for the Sunda region, based on integration of biostratigraphic, lithological and seismic data from Nam Con Son basin, Vietnam. Proc. of the $35^{\text {th }}$ Annu. Conv. Indonesian Petroleum Association 1:1175-1196.

Moulds PJ, 1989. Development of the Bengkalis depression, central Sumatra and its subsequent deformation. A model for other Sumatra grabens? Proc. of the $18^{\text {th }}$ Annu. Conv. Indonesian Petroleum Association 1:217-245.

Muller J, 1963. Palynological study of Holocene peat in Sarawak, p. 147-156. In: Symp. Ecol. Res. in Humid Tropics Vegetation, Kuching, Malaysia.

Muller J, 1966. Montane pollen from the Tertiary of N.W.Borneo. Blumea 14:231-235.

Muller J, 1972. Palynological evidence for change in geomorphology, climate and vegetation in the Mio-Pliocene of Malesia, p. 6-34. In: P. Ashton and M. Ashton (eds.), The Quaternary era in Malesia. Geography Department, University of Hull ed.

Muller J, 1981. Exine architecture and function in some Lythraceae and Sonneratiaceae. Rev. Palaeobot. Palynolo. 35:93-123.

Nayar BK, Devi S, 1964a. Spore morphology of Indian ferns I: Aspidiaceae. Grana 5:80-115.

Nayar BK, Devi S, 1964b. Spore morphology of Indian ferns II: Aspleniaceae and Blechnaceae. Grana 5:225-245.

Nayar BK, Devi S, 1964c. Spore morphology of Indian ferns III: Polypodiaceae. Grana 5:342-395.

Ngah K, Madon M, Tjia HD, 1996. The role of pre-Tertiary fracture in the formation and development of the Malay and Penyu Basins, p. 281-290. In: R. Hall and D.J. Blundell (eds.), Tectonic evolution of Southeast Asia. Geological Society of London Publ.

Ohsawa M, 1990. An interpretation of latitudinal patterns of forest limits in South and East Asian mountains. J. Ecol. 78:326-339.

Ohsawa M, 1992. Structural comparison of tropical montane rain forests along latitudinal and altitudinal gradients in south and east Asia. Vegetatio 97:1-10.

Osbourne PL, 1996. Papua New Guinea introduction. Ramsar Sites Information Service, Wageningen: $57 \mathrm{pp}$. Available from: http://ramsar.wetlands.org/Portals/15/Papua.pdf

Pälike H, Norris RD, Herrle JO, Wilson PA, Coxall HK, Lear CH, Shackleton NJ, Tripati AK, Wade BS, 2006. The heartbeat of the Oligocene climate system. Science 314:1894-1898.

Rau MT, Reagan PD, 2009. Vegetation of the Ok Tedi-Fly rover system. Dev. Earth Environ. Sci. 9:515-547.

Robinson KM, 1987. An overview of source rocks and oils in Indonesia. Proc. of the $16^{\text {th }}$ Annu. Conv. Indonesian Petroleum Association 1:97-122.

Sanders M, 1934. [Die fossilen Fische der Alttertiaren susswasserabelungen aus Mittel-Sumatra. Verhandelingen Geologie-Mijnbouwk Genootsch]. [PhD Thesis in German]. Amsterdam Municipal University ed., Amsterdam: 144 pp.

Saemundssen K, 2010. East African rift system. An overview. Paper presented at course $\mathrm{V}$ on exploration for geothermal resources, organized by UNU-GTP, GDC and KenGen, at Lake Bogoria and Lake Naivasha, Kenya, Oct. 29-Nov. 19, 2010. Available from: http://www.os.is/gogn/unu-gtpsc/UNU-GTP-SC-11-18.pdf

Sathiamurthy E, Voris HK, 2006. Maps of Holocene sea level transgression and submerged lakes on the Sunda Shelf. The Natural History Journal of Chulalonghorn University 2:144. Available from: http://research.rmutp.ac.th/paper/cu/ VorisSupplement.pdf

Shoup RC, Morley RJ, Swiecicki T, Clark SJ, 2013. Tectonostratigraphic framework and Tertiary paleogeography of Southeast Asia: gulf of Thailand to South Vietnam shelf. Houston Geol. Soc. Bull. 55:27-39.

Songtham W, Ratanasthien B, Mildenhall DC, Singharajwarapana S, Kandharosa W, 2003. Oligocene-Miocene climatic changes in Northern Thailand resulting from extrusion tectonics of Southeast Asian landmass. ScienceAsia 29:221-233.

Swiecicki T, Maynard K, 2009. Geology and sequence stratigraphy of block 06/94, Nam Con Son Basin, offshore Vietnam. South East Asia Petroleum Exploration Society Publ., Singapore.

van der Hammen T, 1954. [El desarollo de la flora Colombiana en los periodos geological I. Maestrichtiano hasta Terciario mas Inferior]. [Article in Spanish]. Boletín Geológico 2:49-106.

van Steenis CGGJ, 1957. Outline of vegetation types in Indonesia and some adjacent regions. Proc. $8^{\text {th }}$ Pacific Science Congress (Manila) 4:61-97.

Venkatachala BS, Rawat MS, 1973. Palynology of the Tertiary sediments of the Cauvery Basin. Paleocene to Eocene palynoflora of the subsurface, p. 292-335. In: Proc. of the Seminar in Palaeopalynology and Indian stratigraphy, University of Calcutta, 1971.

Wang XM, Sun XJ, Wang PX, Stattegger K, 2009. Vegetation on the Sundashelf, South China Sea, during the Last Glacial Maximum. Palaeogeogr. Palaeocol. 278:88-97.

Wien JJ, Graham CH, 2005. Graham niche conservatism: integrating ecology, and conservation biology Annu. Rev. Ecol. Evol. S. 36:519-539.

White JM Jr, Wing RS, 1978. Structural development of the South China Sea with particular reference to Indonesia. Proc. of the $7^{\text {th }}$ Annu. Conv. Indonesian Petroleum Association 7:159-174.

Yakzan AM, Jirin S, Shah SSM, Morley RJ, 2010. The major trends of palynomorphs distribution in three fluvial systems, peninsular Malaysia. Paper presented at the $33^{\text {rd }}$ Petroleum Geoscience Conference \& Exhibition, 29 March 2010. Petronas Publ., Kuala Lumpur.

Yamada I, 1998. Tropical rain forests of Southeast Asia, a forest ecologist's view. University of Hawaii Press, Hawaii: 416 pp.

Zachos JC, Dickens GR, Zeebe RE, 2008. An early Cenozoic perspective on greenhouse warming and carbon-cycle dynamics. Nature 451:279-283. 